\title{
Total synthesis of the hydroxyketone kurasoin A using asymmetric phase-transfer alkylation $\dagger$
}

\author{
Merritt B. Andrus, ${ }^{* a}$ Erik J. Hicken, ${ }^{a}$ Jeffrey C. Stephens, ${ }^{a}$ and D. Karl Bedke ${ }^{a}$ \\ Department of Chemistry and Biochemistry, C100 BNSN, Brigham Young \\ University, Provo, UT, 84602, USA. Email: mbandrus@chem.byu.edu

\section{Supplementary Information:}

\author{
S-1 to S-5 Experimental Details \\ S-6 to S-18 NMR Spectra for compounds: $7, \mathbf{8}, \mathbf{1 0}, \mathbf{1 1}, \mathbf{1 7}, \mathbf{1 8}, 1$
}

\section{General Experimental}

Air and water sensitive reactions were performed in flame-dried glassware under a nitrogen atmosphere. Air and moisture sensitive reagents were introduced via dry syringe or cannula. Methylene chloride, toluene, THF, diethyl ether, DMSO, DMF, methanol, triethylamine and acetonitrile were dried by passing through columns of activated alumina. Chloroform, benzene and pyridine were stored over molecular sieves. Reagents were purchased from commercial sources. Flash chromatography was carried out using 60-230 mesh silica gel. Radial chromatography was performed using 1, 2, and $4 \mathrm{~mm}$ plates loaded with 230-400 mesh PF-254 gypsum bound silica. Analytical thinlayer chromatography (TLC) was performed with silica gel $60 \mathrm{~F}_{254}, 0.25 \mathrm{~mm}$ pre-coated TLC plates. TLC plates were visualized using $\mathrm{UV}_{254}$ and cerium molybdate with charring. All ${ }^{1} \mathrm{H}$ NMR spectra were obtained with either 200,300 or $500 \mathrm{MHz}$ spectrometers using TMS $(0.0 \mathrm{ppm})$ or chloroform $(7.27 \mathrm{ppm})$ as an internal reference. Signals are reported as $\mathrm{m}$ (multiplet), s (singlet), d (doublet), t (triplet), q (quartet), bs (broad singlet), $\mathrm{ABq}$ ( $\mathrm{AB}$ quartet) obs (obscured); and coupling constants are reported in hertz $(\mathrm{Hz}) .{ }^{13} \mathrm{C}$ NMR spectra were obtained with either 75 or $125 \mathrm{MHz}$ spectrometers using chloroform (77.2 ppm) as the internal standard. Infrared spectra were obtained on an FTIR instument. Mass spectral data (HRMS, CI, EI, FAB) were obtainedusing standard techniques. Optical rotations were obtained with a polarimeter using the sodium $\mathrm{D}$ line at ambient temperature. Low temperatures were maintained using an immersion cooler with a cooling probe placed in an acetone bath.

\section{Catalyst Preparation}

Park \& Jew - $\boldsymbol{O}$ (9)-allyl- $N$-2',3',4'-triflurorbenzylhydrocinchonidinium bromide (9). ${ }^{1}$ The catalyst was prepared according to the published procedure with the exceptions that

1. Jew, S.; Yoo, M.; Jeong, B.; Park, I. Y.; Park, H. Org. Lett. 2002, 4, 4245. 
in the workup of $\mathrm{N}-\left(2^{\prime}, 3^{\prime}, 4^{\prime}\right.$-Trifluoro)benzylhydrocinchonidinium bromide the reaction mixture was diluted with a 1:40 ratio of $\mathrm{MeOH}$ : diethyl ether to precipitate the catalyst. Also the purification of $O(9)$-allyl- $N-2$ ', 3', 4'-triflurorbenzylhydrocinchonidinium bromide 9 was accomplished via column chromatography $\left(5 \% \mathrm{MeOH} / \mathrm{CH}_{2} \mathrm{Cl}_{2}\right)$ rather than by recrystallization.

\section{$\underline{\text { Substrate Preparation }}$}

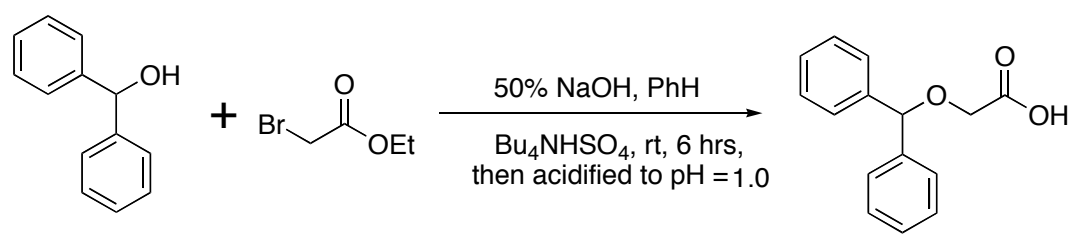

Benzhydryloxy-acetic acid. To an oven dried round bottom flask was added benzhydrol $(5.07 \mathrm{~g}, 27.5 \mathrm{mmol})$ and $270 \mathrm{ml}$ of benzene. Then tetrabutylammonium hydrogensulfate $(0.465 \mathrm{~g}, 1.37 \mathrm{mmol})$ was added with stirring followed by $50 \mathrm{~mL}$ of a $50 \%$ aq. (w/w) $\mathrm{NaOH}$ solution. The reaction was stirred for $30 \mathrm{~min}$ then ethyl bromoacetate $(4.6 \mathrm{~mL}$, $41.3 \mathrm{mmol}$ ) was added dropwise. The solution was allowed to stir at ambient temperature for $24 \mathrm{~h}$. The resulting thick white solution was then diluted with $\mathrm{H}_{2} \mathrm{O}$ and hexanes, the layers were mixed and then separated. The aqueous layer was then carefully acidified, while stirring vigorously, with $6 \mathrm{M} \mathrm{HCl}$ until a $\mathrm{pH}$ of $\sim 7$ was obtained. Then $1 \mathrm{M} \mathrm{HCl}$ was added until the $\mathrm{pH}$ was $\sim 1.4$, as monitored by $\mathrm{pH} 0-2.5$ indicator strips. Next, the resulting white, cloudy solution was extracted with $\mathrm{CH}_{2} \mathrm{Cl}_{2}(5 \times 100 \mathrm{~mL})$. The combined organic layers were dried over $\mathrm{MgSO}_{4}$, filtered and concentrated to provide $6.32 \mathrm{~g}(95 \%)$ of the title compound as a white powder. Observations by TLC and ${ }^{1} \mathrm{H}$ NMR concluded that the product was analytically pure and carried on to the next step. Data are: ${ }^{1} \mathrm{H}$ NMR (DMSO- $\left.d_{6}, 300 \mathrm{MHz}\right) \delta 12.76(\mathrm{bs}, 1 \mathrm{H}), 7.40-7.22(\mathrm{~m}, 10 \mathrm{H}), 5.60(\mathrm{~s}, 1 \mathrm{H}), 3.99(\mathrm{~s}, 2 \mathrm{H})$; ${ }^{13} \mathrm{C}$ NMR (DMSO- $\left.d_{6}, 75 \mathrm{MHz}\right) \delta 171.3,141.7,128.4,127.5,126.8,82.1,65.2$.

2-Benzhydryloxy-1-(2,5-dimethoxy-phenyl)-ethanone (7). To a flame dried round bottom flask was added benzhydryloxy-acetic acid (1.95 g, $8.07 \mathrm{mmol})$ and $32 \mathrm{~mL}$ of $\mathrm{CH}_{2} \mathrm{Cl}_{2}$. The solution was cooled to $0{ }^{\circ} \mathrm{C}$ and $\mathrm{N}, \mathrm{O}$-dimethylhydroxylamine hydrochloride $(1.20 \mathrm{~g}, 12.3 \mathrm{mmol})$ was added in one portion followed by $\mathrm{N}, \mathrm{N}$-diisopropylethylamine (2.10 mL, $12.1 \mathrm{mmol})$. Then 4-(dimethylamino)pyridine (0.156 g, $1.27 \mathrm{mmol})$ was added followed by 1-[3-(dimethylamino)propyl]-3-ethylcarbodiimide hydrochloride $(1.56 \mathrm{~g}$, $8.12 \mathrm{mmol}$ ). The reaction was stirred at $0{ }^{\circ} \mathrm{C}$ for $1 \mathrm{~h}$ then warmed to ambient temperature where it stirred for an additional $24 \mathrm{~h}$. The solution was then diluted with $\mathrm{CH}_{2} \mathrm{Cl}_{2}(80 \mathrm{~mL})$ and $\mathrm{H}_{2} \mathrm{O}(80 \mathrm{~mL})$. The layers were mixed and separated, and the aqueous layer was extracted with $\mathrm{CH}_{2} \mathrm{Cl}_{2}(3 \times 70 \mathrm{~mL})$. The combined organic layers were washed with an aqueous $1 \mathrm{M} \mathrm{H}_{3} \mathrm{PO}_{4}$ solution, then with a saturated aqueous $\mathrm{NaHCO}_{3}$ solution and finally with a saturated aqueous $\mathrm{NaCl}$ solution. The organic layer was then dried over $\mathrm{MgSO}_{4}$, filtered and concentrated in vасио. The crude amide was filtered through a silica gel plug eluting with EtOAc, the filtrate was then concentrated and thoroughly dried in vacuo resulting in the isolation of a pale yellow solid. Dry THF $(40.0 \mathrm{~mL})$ was added to the crude mixture followed by cooling to $-40{ }^{\circ} \mathrm{C}$. To a separate flame dried round bottom 
flask was added 1,4-dimethoxybenzene $(1.46 \mathrm{~g}, 10.6 \mathrm{mmol})$ and $18.0 \mathrm{~mL}$ of THF. The solution was cooled to $0{ }^{\circ} \mathrm{C}$ and then, with stirring, $\mathrm{n}-\mathrm{BuLi}(6.3 \mathrm{~mL}, 1.6 \mathrm{M}$ in hexanes, $10.1 \mathrm{mmol}$ ) was added dropwise over $30 \mathrm{~min}$ to produce a faint yellow solution. The solution was allowed to stir for $3 \mathrm{hr}$ at $0{ }^{\circ} \mathrm{C}$ then added via cannula to the previously described, pre-cooled solution of the crude 2-benzhydryloxy- $N$-methoxy- $N$-methylacetamide solution. The resulting solution was allowed to stir for $15 \mathrm{~min}$ at $-40{ }^{\circ} \mathrm{C}$ then quenched by the addition of a saturated aqueous $\mathrm{NH}_{4} \mathrm{Cl}$ solution $(10 \mathrm{~mL})$. The reaction was warmed to ambient temperature and the solution partitioned between a saturated aqueous $\mathrm{NaCl}$ solution and a 1:1 mixture of $\mathrm{Et}_{2} \mathrm{O}: \mathrm{CH}_{2} \mathrm{Cl}_{2}$. The layers were separated and the aqueous layer extracted with (1:1) $\mathrm{Et}_{2} \mathrm{O}: \mathrm{CH}_{2} \mathrm{Cl}_{2}(3 \times 50 \mathrm{~mL})$. The combined organic layers were dried over $\mathrm{MgSO}_{4}$, filtered and concentrated. The crude product was purified via column chromatography ( $20 \% \mathrm{EtOAc/hexanes)} \mathrm{to} \mathrm{produce} 2.24 \mathrm{~g}(84 \%)$ of the desired compound 7 as an off-white crystalline solid. Data are: TLC $\mathrm{R}_{\mathrm{f}}=0.23(20 \%$ EtOAc/hexanes); ${ }^{1} \mathrm{H} \mathrm{NMR}\left(\mathrm{CDCl}_{3}, 300 \mathrm{MHz}\right) \delta 7.43-7.20(\mathrm{~m}, 11 \mathrm{H}), 7.00(\mathrm{dd}, J=3$, $9 \mathrm{~Hz}, 1 \mathrm{H}), 6.81(\mathrm{~d}, J=9 \mathrm{~Hz}, 1 \mathrm{H}), 5.62(\mathrm{~s}, 1 \mathrm{H}), 4.71(\mathrm{~s}, 2 \mathrm{H}), 3.75(\mathrm{~s}, 3 \mathrm{H}), 3.69(\mathrm{~s}, 3 \mathrm{H}) ;{ }^{13} \mathrm{C}$ $\mathrm{NMR}\left(\mathrm{CDCl}_{3}, 75 \mathrm{MHz}\right) \delta 197.7,153.7,141.8,128.5,127.7,127.5,125.9,121.1,113.7$, 113.1, 83.4, 75.1, 56.0, 55.9; $\mathrm{mp}=70-72^{\circ} \mathrm{C}$; HRMS $\left(\mathrm{FAB}^{+}\right)$found $385.1412[\mathrm{M}+\mathrm{Na}]^{+}$, calcd 385.1410 for $\mathrm{C}_{23} \mathrm{H}_{22} \mathrm{O}_{4} \mathrm{Na}$; Anal. calcd for $\mathrm{C}_{23} \mathrm{H}_{22} \mathrm{O}_{4}: \mathrm{C}, 76.22 ; \mathrm{H}, 6.12$. Found: $\mathrm{C}$, 75.98; H, 6.09.

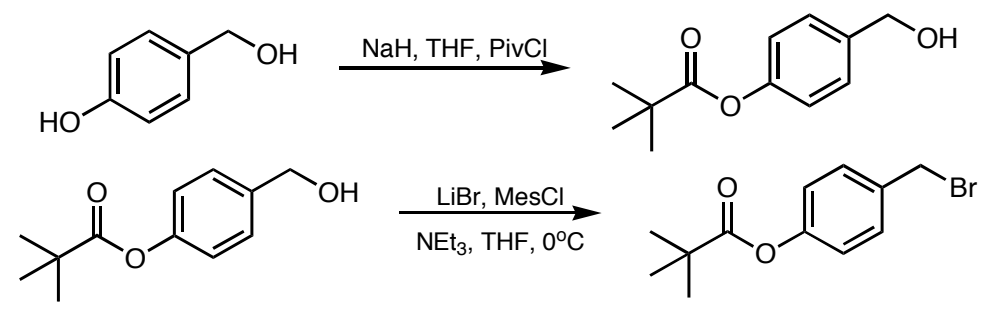

4-(bromomethyl)phenyl pivalate (8). To a flame dried $500 \mathrm{~mL}$ round bottom flask was added $\mathrm{NaH}$ (dry 95\%, $2.13 \mathrm{~g}, 88.9 \mathrm{mmol}$ ) and $400 \mathrm{~mL}$ of THF. The suspension was cooled to $0{ }^{\circ} \mathrm{C}$ under $\mathrm{N}_{2}$. Then 4-hydroxybenzyl alcohol (10.06 g, $\left.80.9 \mathrm{mmol}\right)$ was added in one portion. The mixture stirred at $0{ }^{\circ} \mathrm{C}$ until bubbling ceased at which time the reaction was warmed to ambient temperature and stirred for an additional $30 \mathrm{~min}$. The mixture was again cooled to $0{ }^{\circ} \mathrm{C}$ and trimethylacetyl chloride $(10.95 \mathrm{~mL}, 88.9 \mathrm{mmol})$ was added slowly. After stirring for $30 \mathrm{~min}$ at $0{ }^{\circ} \mathrm{C}$ the mixture was warmed to ambient temperature and stirred for $2 \mathrm{~h}$. Then $100 \mathrm{~mL}$ of a saturated aqueous $\mathrm{NaHCO}_{3}$ solution was added followed by $300 \mathrm{~mL}$ of $\mathrm{H}_{2} \mathrm{O}$. The mixture was extracted with EtOAc (3 x 100 $\mathrm{mL}$ ), the combined organic layers were washed with a saturated aqueous $\mathrm{NaCl}$ solution, dried over $\mathrm{MgSO}_{4}$, filtered, and concentrated. The crude product was purified via column chromatography (40\% EtOAc/hex) to afford $13.40 \mathrm{~g}$ (80\%) of 4-(hydroxymethyl)phenyl pivalate as a pale yellow oil which solidified in cold storage. Data are: ${ }^{1} \mathrm{H} \mathrm{NMR}\left(\mathrm{CDCl}_{3}\right.$, $300 \mathrm{MHz}) \delta$ 7.38-7.36 (m, 2H), 7.06-7.03 (m, 2H), 4.67 (s, 2H), 1.84 (bs, 1H), 1.37 (s, $9 \mathrm{H})$. To an oven dried $500 \mathrm{~mL}$ round bottom flask was added $\mathrm{LiBr}(55.84 \mathrm{~g}, 643 \mathrm{mmol})$, THF (120 mL) and $\mathrm{NEt}_{3}(22.4 \mathrm{~mL}, 160.8 \mathrm{mmol})$. Then 4-(hydroxymethyl)phenyl pivalate $(13.4 \mathrm{~g}, 64.3 \mathrm{mmol})$ was added as a THF solution $(200 \mathrm{~mL})$. The mixture was cooled to 0 ${ }^{\circ} \mathrm{C}$ and methanesulfonyl chloride $(10.45 \mathrm{~mL}, 135 \mathrm{mmol})$ was added dropwise. The solution stirred at $0{ }^{\circ} \mathrm{C}$ for $2 \mathrm{~h}$ at which time $\mathrm{H}_{2} \mathrm{O}(200 \mathrm{~mL})$ was added. The solution was 
warmed to ambient temperature and extracted with $\mathrm{CH}_{2} \mathrm{Cl}_{2}(3 \times 100 \mathrm{~mL})$. The combined organic layers were washed with a saturated aqueous $\mathrm{NaHCO}_{3}$ solution, dried over $\mathrm{MgSO}_{4}$, filtered and concentrated. The crude product was purified via column chromatography (10\% EtOAc/hex) to provide $14.15 \mathrm{~g}(81 \%)$ of the desired compound 8 as a white solid. Data are: $\mathrm{mp}=58-60{ }^{\circ} \mathrm{C} ;{ }^{1} \mathrm{H} \mathrm{NMR}\left(\mathrm{CDCl}_{3}, 500 \mathrm{MHz}\right) \delta 7.41-7.40(\mathrm{~m}$, 2H), 7.05-7.03 (m, 2H), 4.50 (s, 2H), $1.36(\mathrm{~s}, 9 \mathrm{H}) ;{ }^{13} \mathrm{C} \mathrm{NMR}\left(\mathrm{CDCl}_{3}, 125 \mathrm{MHz}\right) \delta 177.1$, 151.2, 135.3, 130.4, 122.1, 39.3, 33.0, 27.3; HRMS $\left(\mathrm{EI}^{+}\right)$found $270.0255 \mathrm{M}^{+}$, calcd 270.0255 for $\mathrm{C}_{12} \mathrm{H}_{15} \mathrm{O}_{2} \mathrm{Br}$.

(S)-4-(2-(benzhydryloxy)-3-(2,5-dimethoxyphenyl)-3-oxopropyl)phenyl pivalate (10). To a flame dried round bottom flask was added 2-benzhydryloxy-1-(2,5-dimethoxyphenyl)-ethanone 7 (1.0g, $2.76 \mathrm{mmol}), O(9)$-allyl- $N$-2',3',4'-triflurorbenzyl hydrocinchonidinium bromide $9(0.157 \mathrm{~g}, 0.28 \mathrm{mmol}), \mathrm{CH}_{2} \mathrm{Cl}_{2}(14 \mathrm{~mL})$ and hexane $(14$ $\mathrm{mL})$. The solution was cooled to $-35^{\circ} \mathrm{C}$ and then $\mathrm{CsOH} \bullet \mathrm{H}_{2} \mathrm{O}(2.32 \mathrm{~g}, 13.8 \mathrm{mmol})$ was added in one portion. The mixture stirred for 10 minutes, at which time 4-(bromomethyl) phenyl pivalate $8(3.74 \mathrm{~g}, 13.8 \mathrm{mmol})$ was added. The mixture stirred at $-35^{\circ} \mathrm{C}$ for $24 \mathrm{~h}$, at which time the reaction was diluted with $\mathrm{Et}_{2} \mathrm{O}(400 \mathrm{~mL})$ and $\mathrm{H}_{2} \mathrm{O}(150 \mathrm{~mL})$. The layers were mixed and then separated and the organic layer was washed with $\mathrm{H}_{2} \mathrm{O}(2 \times 50 \mathrm{~mL})$ followed by a saturated aqueous solution of $\mathrm{NaCl}$, then dried over $\mathrm{MgSO}_{4}$. The mixture was filtered, the solvent removed in vacuo and the crude residue purified by column chromatography (10 - 20\% EtOAc/hexane gradient) to afford $1.45 \mathrm{~g}(95 \%)$ of the desired compound $\mathbf{1 0}$ as a colorless oil. Early column fractions were collected and concentrated to produce $2.82 \mathrm{~g}$ (94\% recovery) of analytically pure 4-(bromomethyl)phenyl pivalate 8 . Data are; $[\alpha]_{\mathrm{D}}{ }^{23}+14.0^{\circ}, \mathrm{c} 1.3, \mathrm{CHCl}_{3} ;{ }^{1} \mathrm{H} \mathrm{NMR}\left(\mathrm{CDCl}_{3}, 500 \mathrm{MHz}\right) \delta 7.32-6.81$ (m's, $17 \mathrm{H}), 5.42(\mathrm{~s}, 1 \mathrm{H}), 5.12(\mathrm{dd}, J=3.0,10.0 \mathrm{~Hz}, 1 \mathrm{H}), 3.76(\mathrm{~s}, 3 \mathrm{H}), 3.56(\mathrm{~s}, 3 \mathrm{H}), 3.03$ (dd, $J$ $=3.0,14.0 \mathrm{~Hz}, 1 \mathrm{H}), 2.86(\mathrm{dd}, J=10.0,13.5 \mathrm{~Hz}, 1 \mathrm{H}), 1.37(\mathrm{~s}, 9 \mathrm{H}) ;{ }^{13} \mathrm{C} \mathrm{NMR}\left(\mathrm{CDCl}_{3}, 125\right.$ MHz) $\delta$ 202.0, 177.4, 154.0, 152.8, 150.0, 142.7, 141.3, 135.9, 130.8, 128.5, 128.4, 127.9, 127.7, 127.4, 127.3, 121.4, 120.7, 114.3, 113.6, 82.7, 82.6, 56.1, 56.0, 39.3, 38.5, 27.5; HRMS $\left(\mathrm{FAB}^{+}\right.$) found 575.2420 [M+Na] ${ }^{+}$, calcd 575.2404 for $\mathrm{C}_{35} \mathrm{H}_{36} \mathrm{O}_{6} \mathrm{Na}$; The enantioselectivity was determined by chiral HPLC (DAICEL Chiralpack AD column, $10 \% \mathrm{EtOH} / \mathrm{hexane}, 1.0 \mathrm{~mL} / \mathrm{min}, 23^{\circ} \mathrm{C}, \lambda=254 \mathrm{~nm}$, retention times: $S$ (major) $7.9 \mathrm{~min}, R$ (minor) $6.1 \mathrm{~min}, 83 \% \mathrm{ee}$ ).

(S)-2,5-dimethoxyphenyl 2-hydroxy-3-(4-phenylpivalate)propanoate (11). To a 250 $\mathrm{mL}$ round bottom flask containing $(S)$-4-(2-(benzhydryloxy)-3-(2,5-dimethoxyphenyl)-3oxopropyl)phenyl pivalate $10(1.315 \mathrm{~g}, 2.38 \mathrm{mmol})$ was added $\mathrm{CH}_{2} \mathrm{Cl}_{2}(48 \mathrm{~mL})$ and the solution was cooled to $-78{ }^{\circ} \mathrm{C}$. Then $\mathrm{TiCl}_{4}(1.0 \mathrm{M}$ in $\mathrm{CH} 2 \mathrm{Cl} 2,2.38 \mathrm{~mL})$ was added dropwise over $5 \mathrm{~min}$ and the reaction stirred at $-78{ }^{\circ} \mathrm{C}$ for $20 \mathrm{~min}$. Then a saturated aqueous $\mathrm{NaHCO}_{3}$ solution was added $(50 \mathrm{~mL})$ and the mixture warmed to ambient temperature. The layers were separated and the aqueous phase extracted with $\mathrm{CH}_{2} \mathrm{Cl}_{2}(3 \mathrm{x}$ $30 \mathrm{~mL}$ ). The combined organic layers were washed with a saturated aqueous $\mathrm{NaCl}$ solution, dried over $\mathrm{Na}_{2} \mathrm{SO}_{4}$, filtered and concentrated. The crude product was purified via radial chromatography (4 mm plate, $20 \% \mathrm{EtOAc/hex}$ ) to afford $0.843 \mathrm{~g}(92 \%)$ of $(S)$ 4-(3-(2,5-dimethoxyphenyl)-2-hydroxy-3-oxopropyl)phenyl pivalate as a colorless viscous oil. Data are: $[\alpha]_{\mathrm{D}}{ }^{23}-34.4^{\circ}, \mathrm{c} 1.4, \mathrm{CHCl}_{3} ;{ }^{1} \mathrm{H} \mathrm{NMR}\left(\mathrm{CDCl}_{3}, 500 \mathrm{MHz}\right) \delta 7.34(\mathrm{~d}$, $J=3.5 \mathrm{~Hz}, 1 \mathrm{H}), 7.17-7.11(\mathrm{~m}, 3 \mathrm{H}), 6.97-6.94(\mathrm{~m}, 3 \mathrm{H}), 5.38-5.37$ (m, 1H), 3.89 (s, 3H), 
3.87 (obs m, 1H), 3.81 (s, 3H), 3.13 (dd, $J=3.0,14.0 \mathrm{~Hz}, 1 \mathrm{H}), 2.73$ (dd, $J=7.0,14.0 \mathrm{~Hz}$, $1 \mathrm{H}), 1.35(\mathrm{~s}, 9 \mathrm{H}) ;{ }^{13} \mathrm{C} \mathrm{NMR}\left(\mathrm{CDCl}_{3}, 125 \mathrm{MHz}\right) \delta 201.9,177.2,154.0,153.5,149.9$, 135.2, 130.5, 124.4, 122.1, 121.2, 114.7, 113.4, 77.5, 56.2, 56.0, 40.3, 39.2, 27.3; HRMS $\left(\mathrm{FAB}^{+}\right)$found $409.1613[\mathrm{M}+\mathrm{Na}]^{+}$, calcd 409.1622 for $\mathrm{C}_{22} \mathrm{H}_{26} \mathrm{O}_{6} \mathrm{Na}$. To a flame dried round bottom flask was added activated 4 angstrom molecular sieves $(0.500 \mathrm{~g})$, trans- $N, N$-bis $(p$ toluenesulfonyl)-1,2-cyclohexanediamine (0.840 g, $1.99 \mathrm{mmol}), \mathrm{K}_{2} \mathrm{CO}_{3}(0.550 \mathrm{~g}, 3.98$ $\mathrm{mmol})$ and $15.0 \mathrm{~mL}$ of $\mathrm{CH}_{2} \mathrm{Cl}_{2}$. The mixture was cooled to $0{ }^{\circ} \mathrm{C}$ and $\mathrm{SnCl}_{4}(2.0 \mathrm{~mL}, 1.0$ $\mathrm{M}$ in $\left.\mathrm{CH}_{2} \mathrm{Cl}_{2}\right)$ was added followed by bis(trimethylsilyl)peroxide $(0.855 \mathrm{~mL}, 3.98 \mathrm{mmol})$. The mixture was stirred at $0{ }^{\circ} \mathrm{C}$ for 5 minutes, then $(S)$-4-(3-(2,5-dimethoxyphenyl)-2hydroxy-3-oxopropyl)phenyl pivalate $(0.770 \mathrm{~g}, 1.99 \mathrm{mmol})$ was added as a $\mathrm{CH}_{2} \mathrm{Cl}_{2}$ solution $\left(16.0 \mathrm{~mL}+4.0 \mathrm{~mL}\right.$ round bottom rinse). The reaction stirred at $0{ }^{\circ} \mathrm{C}$ for $75 \mathrm{~min}$, at which time the reaction was quenched by the addition of saturated aqueous $\mathrm{NaHCO}_{3}$ $(20 \mathrm{~mL})$ followed by a saturated aqueous $\mathrm{Na}_{2} \mathrm{~S}_{2} \mathrm{O}_{3}$ solution $(15 \mathrm{~mL})$. The mixture was warmed to ambient temperature and filtered through a celite pad. The product was rinsed off the celite with $\mathrm{CH}_{2} \mathrm{Cl}_{2}(150 \mathrm{~mL})$ and the layers were then separated. The organic layer was washed with a saturated aqueous $\mathrm{NaCl}$ solution, dried over $\mathrm{Na}_{2} \mathrm{SO}_{4}$, filtered, concentrated and purified via flash column chromatography $\left(50 \% \mathrm{Et}_{2} \mathrm{O} /\right.$ hexanes) to provide $0.665 \mathrm{~g}(83 \%)$ of the title compound 11 as a fluffy white solid. Then, $0.510 \mathrm{~g}$ of the white solid was dissolved in a minimal amount of warm $\operatorname{Et}_{2} \mathrm{O}$ :hexanes $(1: 1)$ and the product was allowed to recrystallize overnight. Removal of the residual solvent and subsequent drying of the needle-like crystals provided $0.380 \mathrm{~g}(75 \%)$ of the title compound with $96 \%$ ee. Data are: $[\alpha]_{\mathrm{D}}{ }^{23}-7.3^{\circ}, \mathrm{c} 1.0, \mathrm{CHCl}_{3} ; \mathrm{mp}=94-96{ }^{\circ} \mathrm{C} ;{ }^{1} \mathrm{H} \mathrm{NMR}$ $\left(\mathrm{CDCl}_{3}, 500 \mathrm{MHz}\right) \delta 7.38-7.37(\mathrm{~m}, 2 \mathrm{H}), 7.05-7.02(\mathrm{~m}, 2 \mathrm{H}), 6.92(\mathrm{~d}, J=8.5 \mathrm{~Hz}, 1 \mathrm{H}), 6.77$ $(\mathrm{dd}, J=3.0,9.0 \mathrm{~Hz}, 1 \mathrm{H}), 6.59(\mathrm{~d}, J=3.0,1 \mathrm{H}), 4.73-4.70(\mathrm{~m}, 1 \mathrm{H}), 3.78(\mathrm{~s}, 3 \mathrm{H}), 3.76(\mathrm{~s}$, $3 \mathrm{H}), 3.34(\mathrm{dd}, J=3.5,14.0 \mathrm{~Hz}, 1 \mathrm{H}), 3.15(\mathrm{dd}, J=7.0,14.0 \mathrm{~Hz}, 1 \mathrm{H}), 2.79-2.76(\mathrm{~m}, 1 \mathrm{H})$, $1.36(\mathrm{~s}, 9 \mathrm{H}) ;{ }^{13} \mathrm{C} \mathrm{NMR}\left(\mathrm{CDCl}_{3}, 125 \mathrm{MHz}\right) \delta 177.2,172.4,153.9,150.3,145.2,139.8$, 133.9, 130.9, 121.6, 113.6, 112.1, 109.3, 71.4, 56.6, 56.0, 40.0, 39.3, 27.3; HRMS

$\left(\mathrm{FAB}^{+}\right)$found $425.1583[\mathrm{M}+\mathrm{Na}]^{+}$, calcd 425.1571 for $\mathrm{C}_{22} \mathrm{H}_{26} \mathrm{O}_{7} \mathrm{Na}$. The enantiomeric excess was determined by chiral HPLC (DAICEL Chiralpack AD column, 10\% IPA/hexane, $1.0 \mathrm{~mL} / \mathrm{min}, 23^{\circ} \mathrm{C}, \lambda=254 \mathrm{~nm}$, retention times: $S$ (major) $14.4 \mathrm{~min}, R$ (minor) $11.4 \mathrm{~min}, 96 \% \mathrm{ee}$ ). 


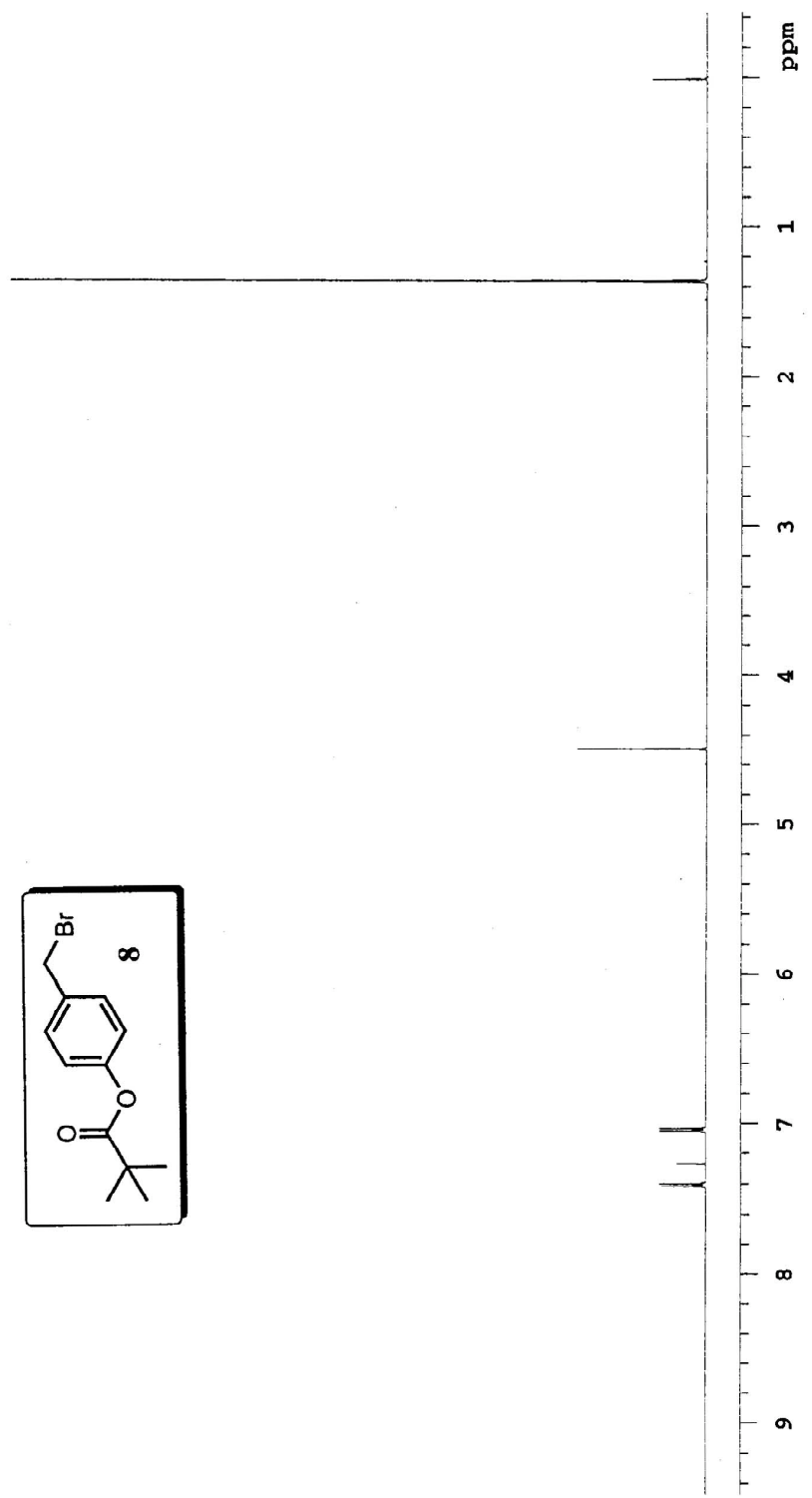



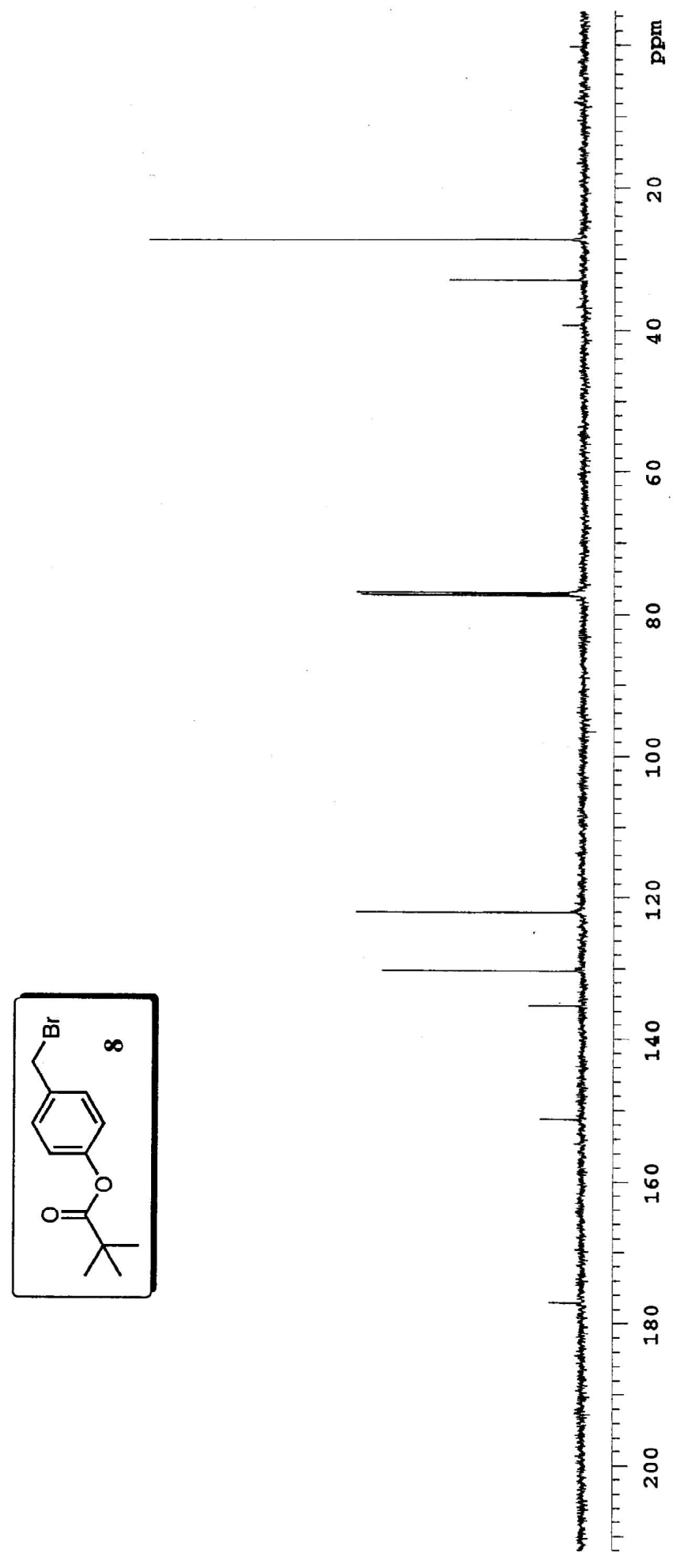
S-8

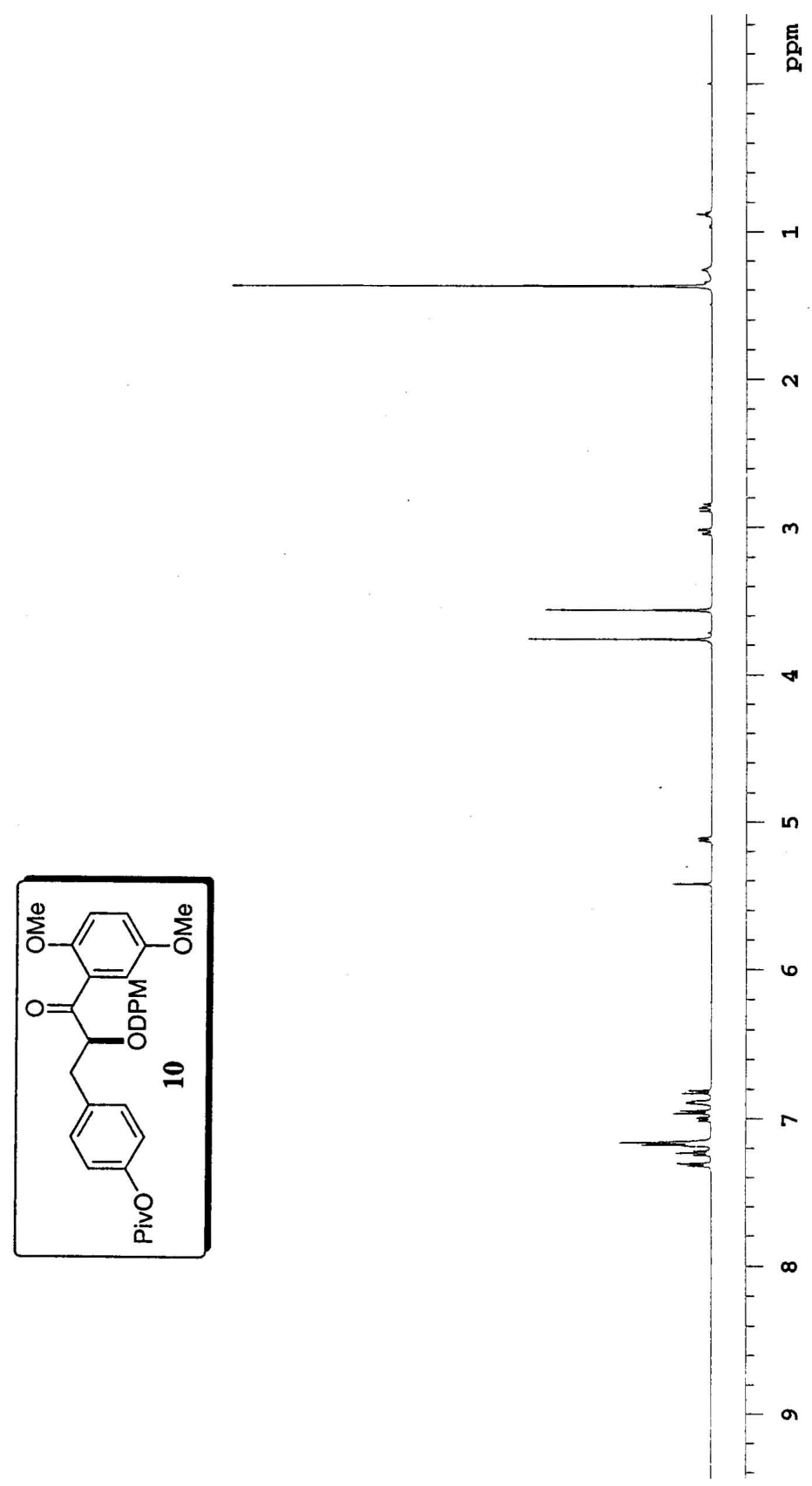




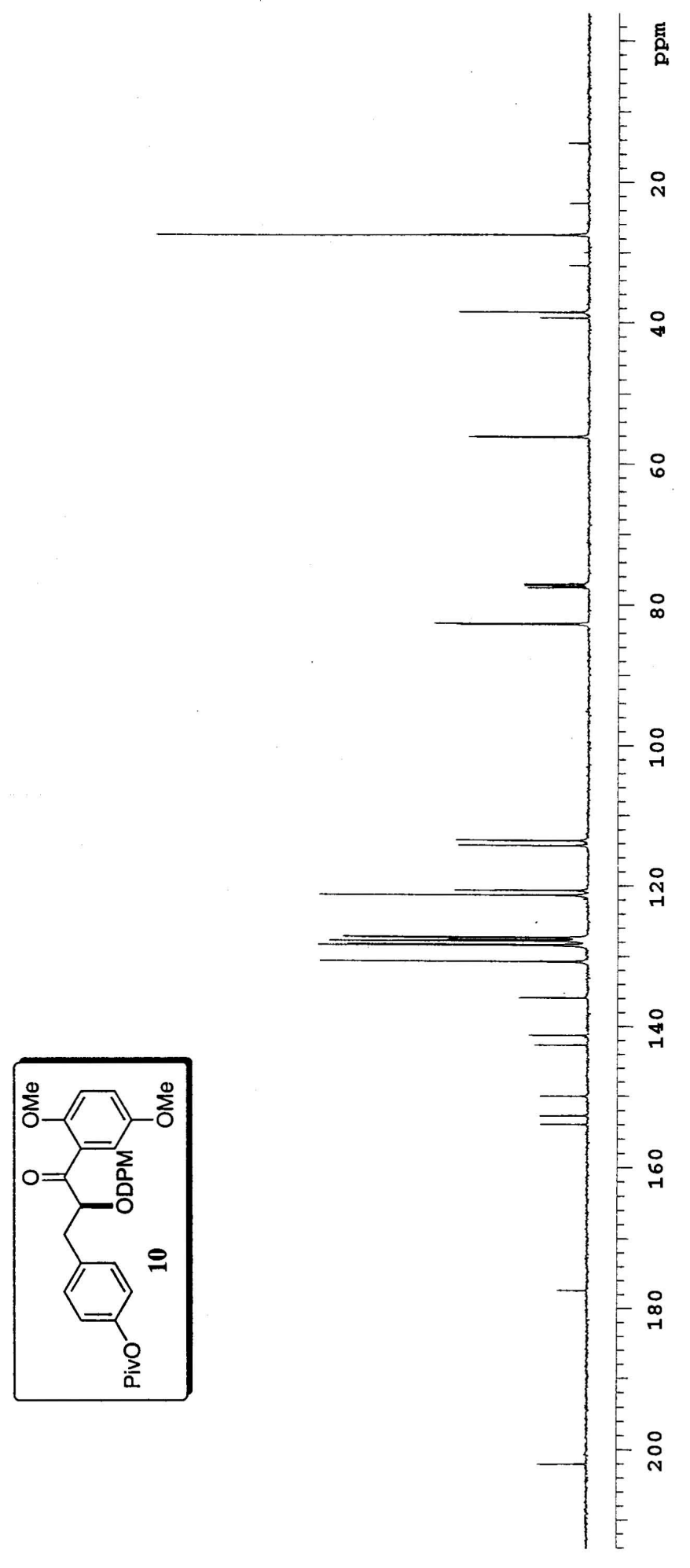


S-10

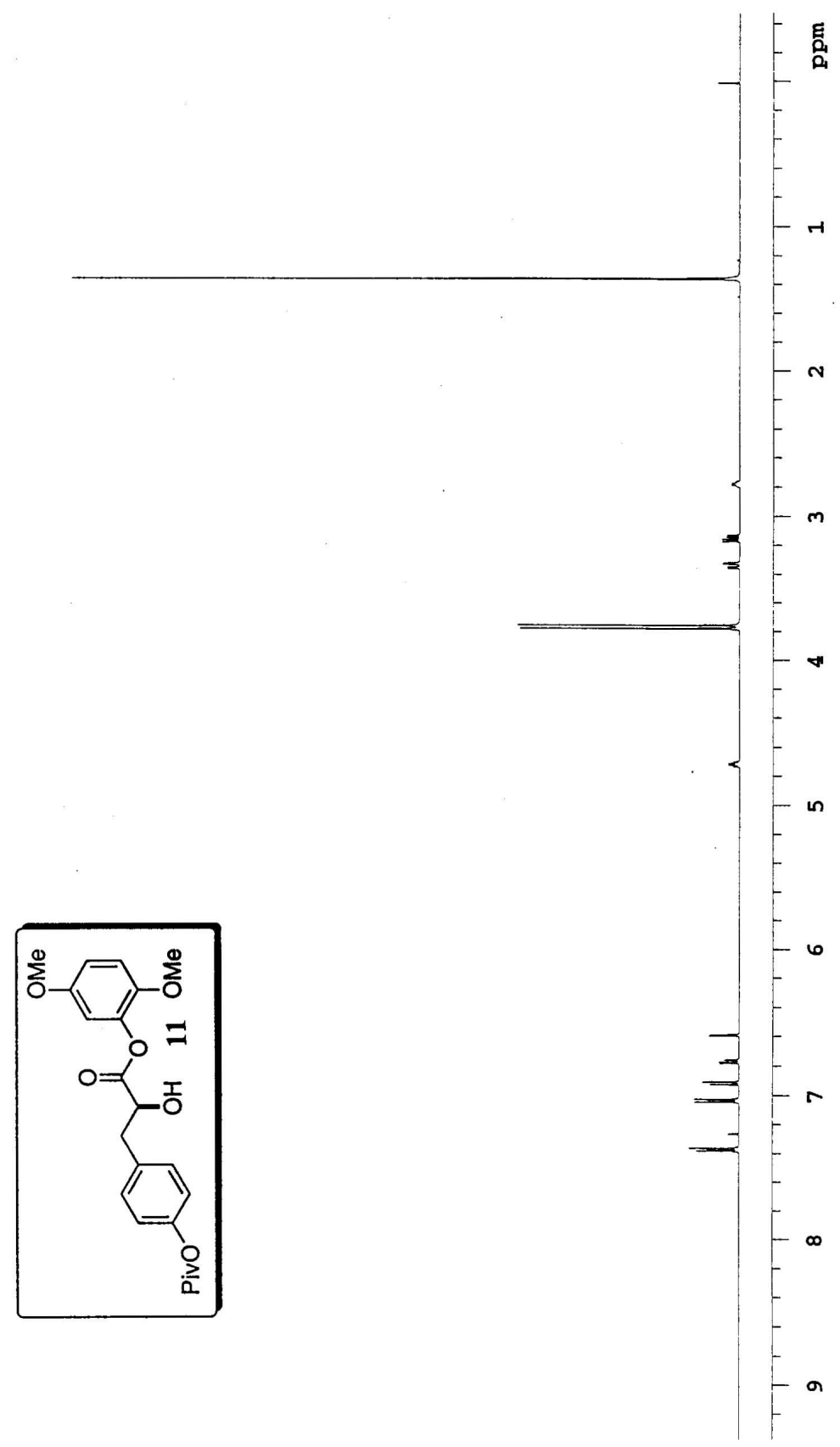


S-11

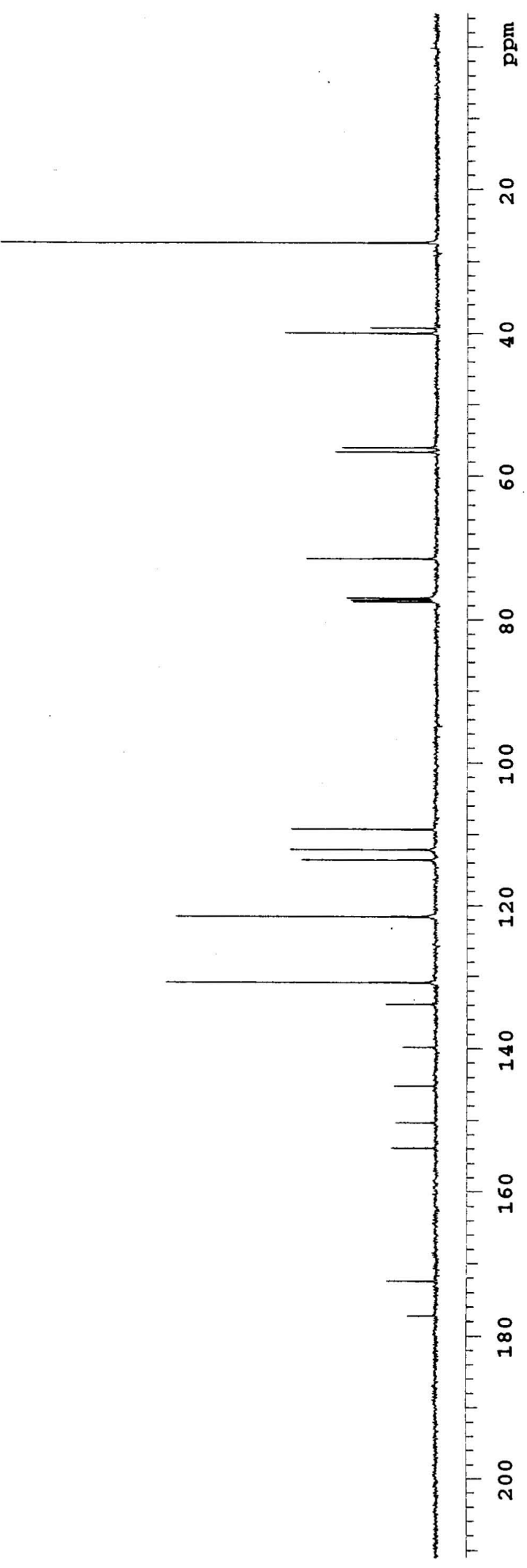


S-12

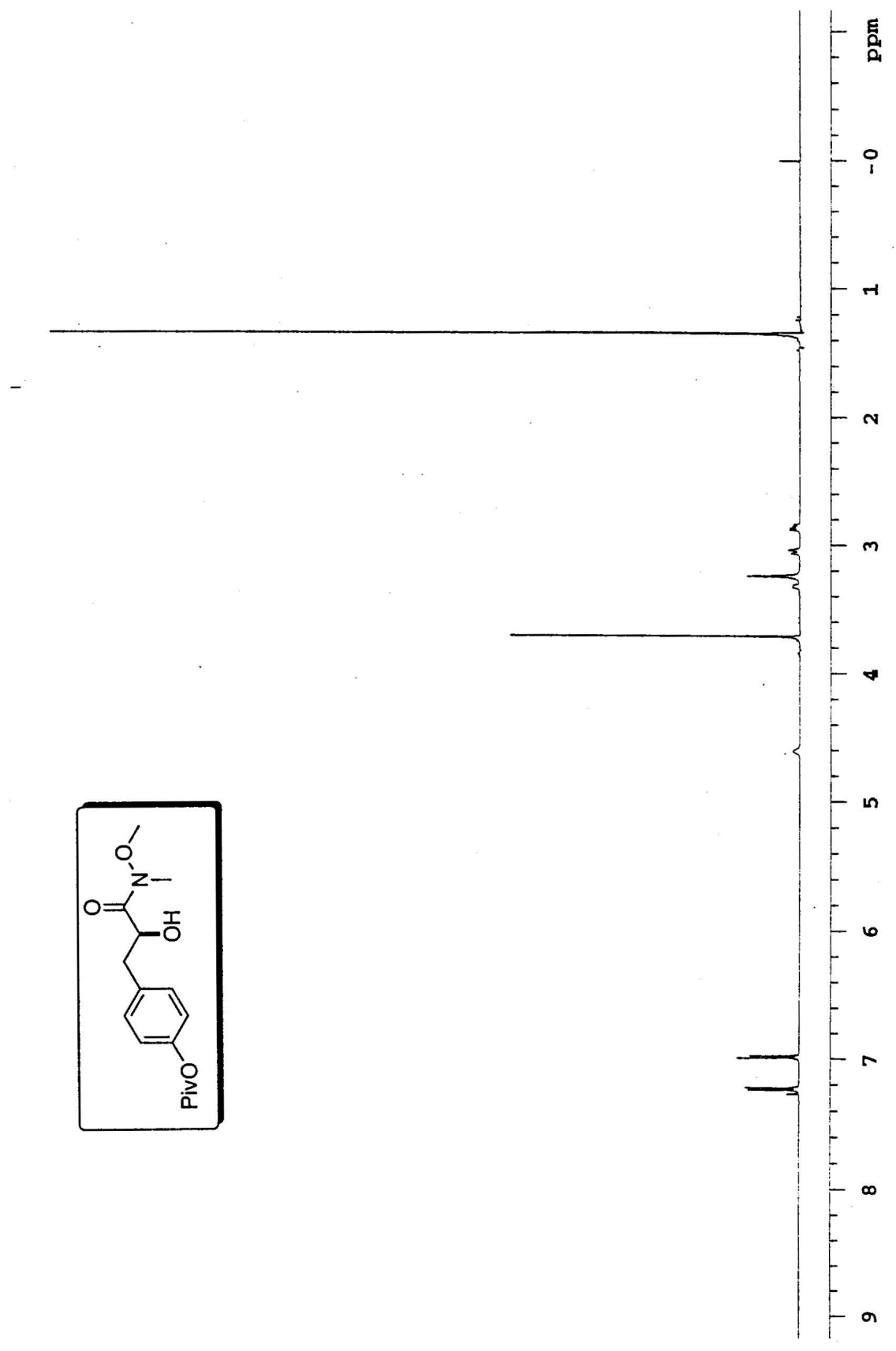


S-13

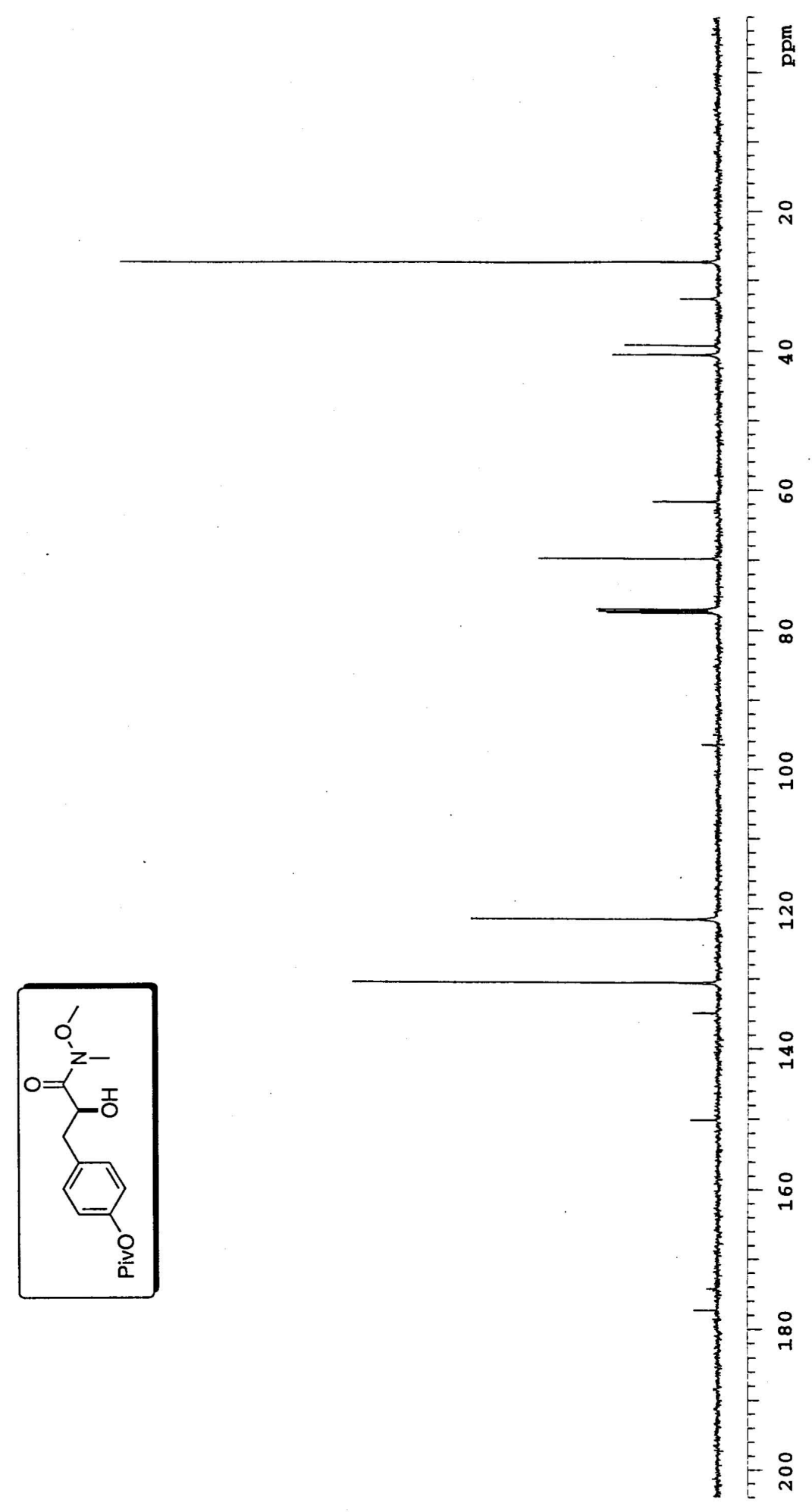


S-14

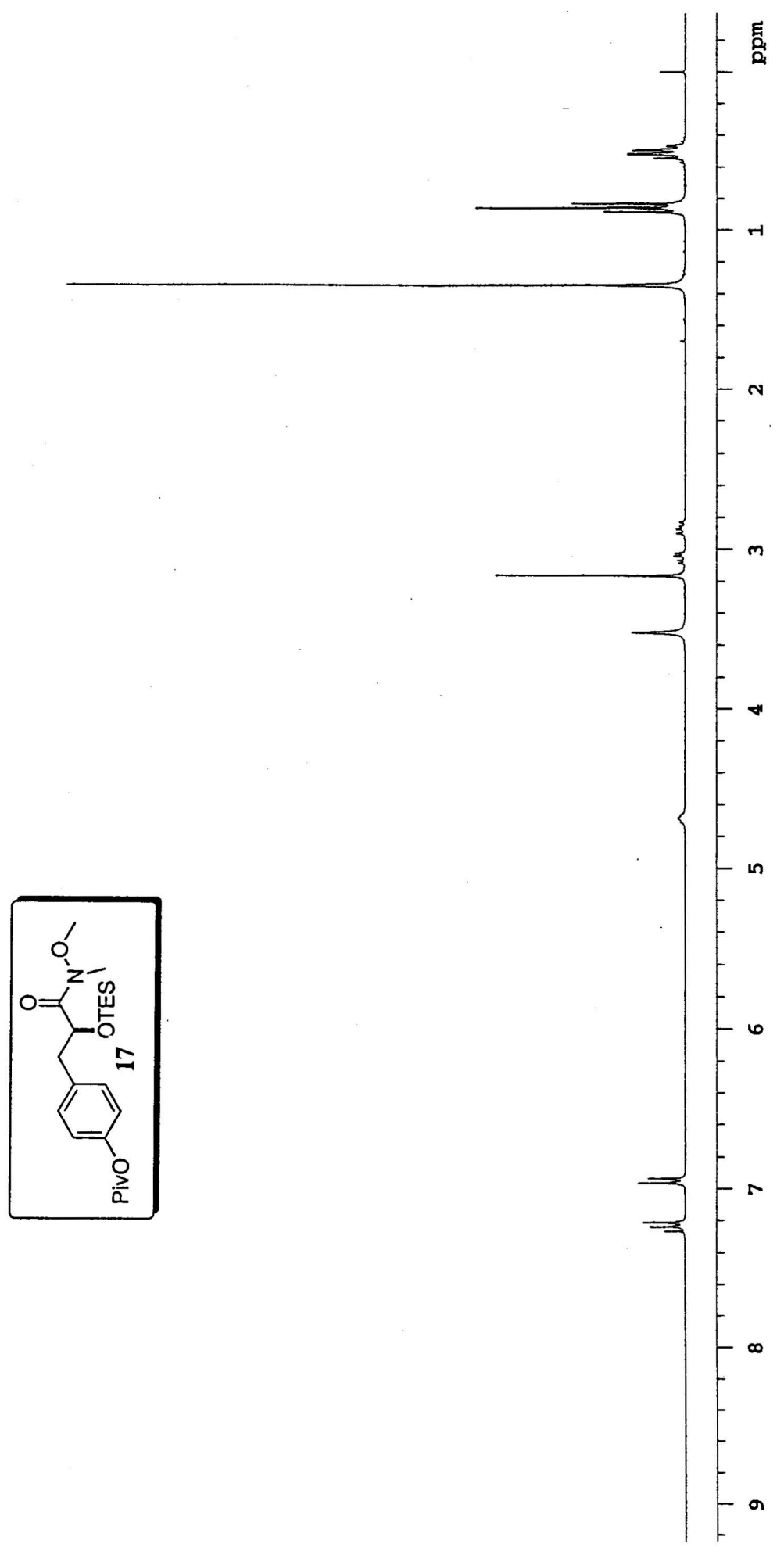


S-15

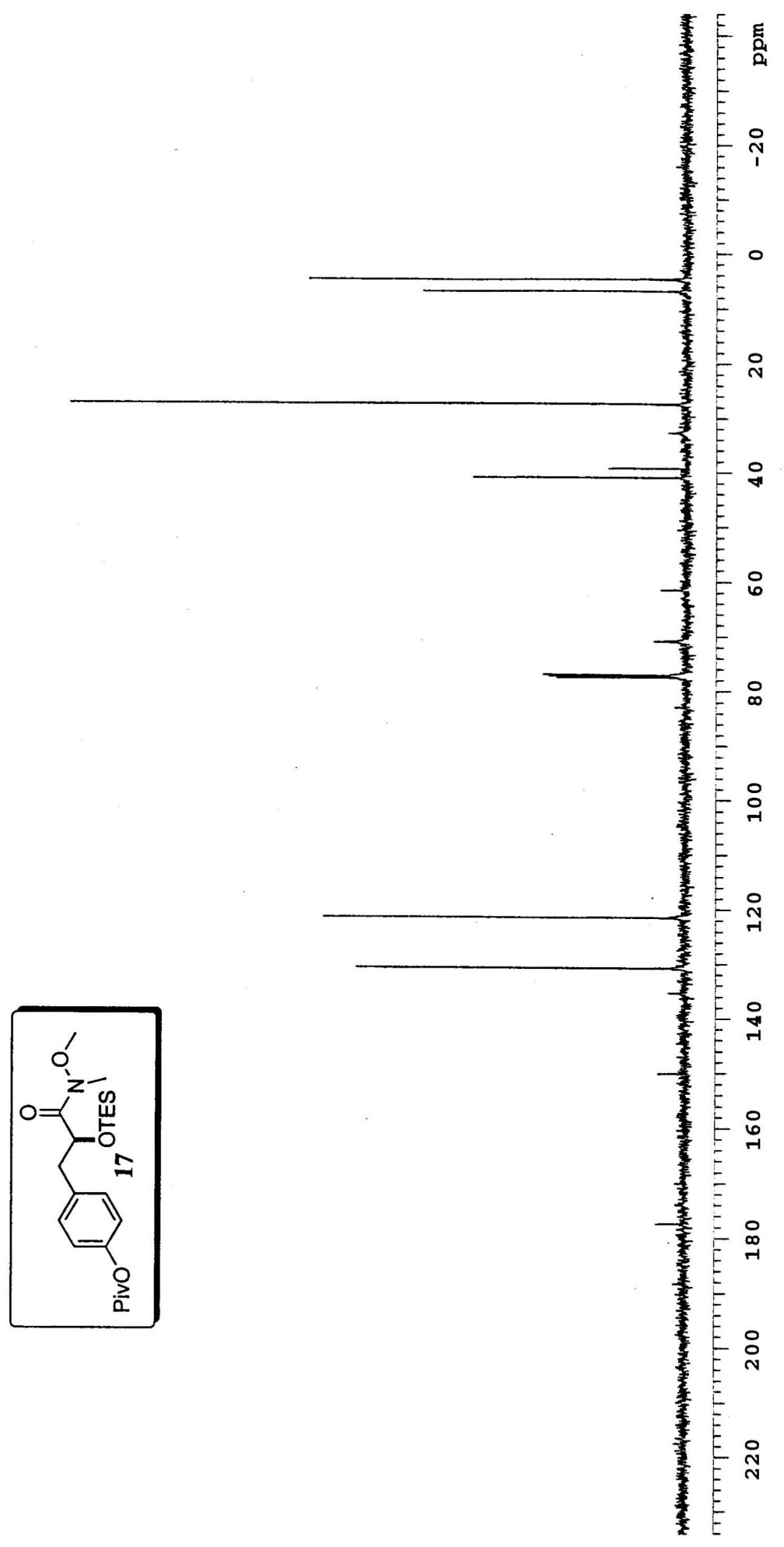


S-16
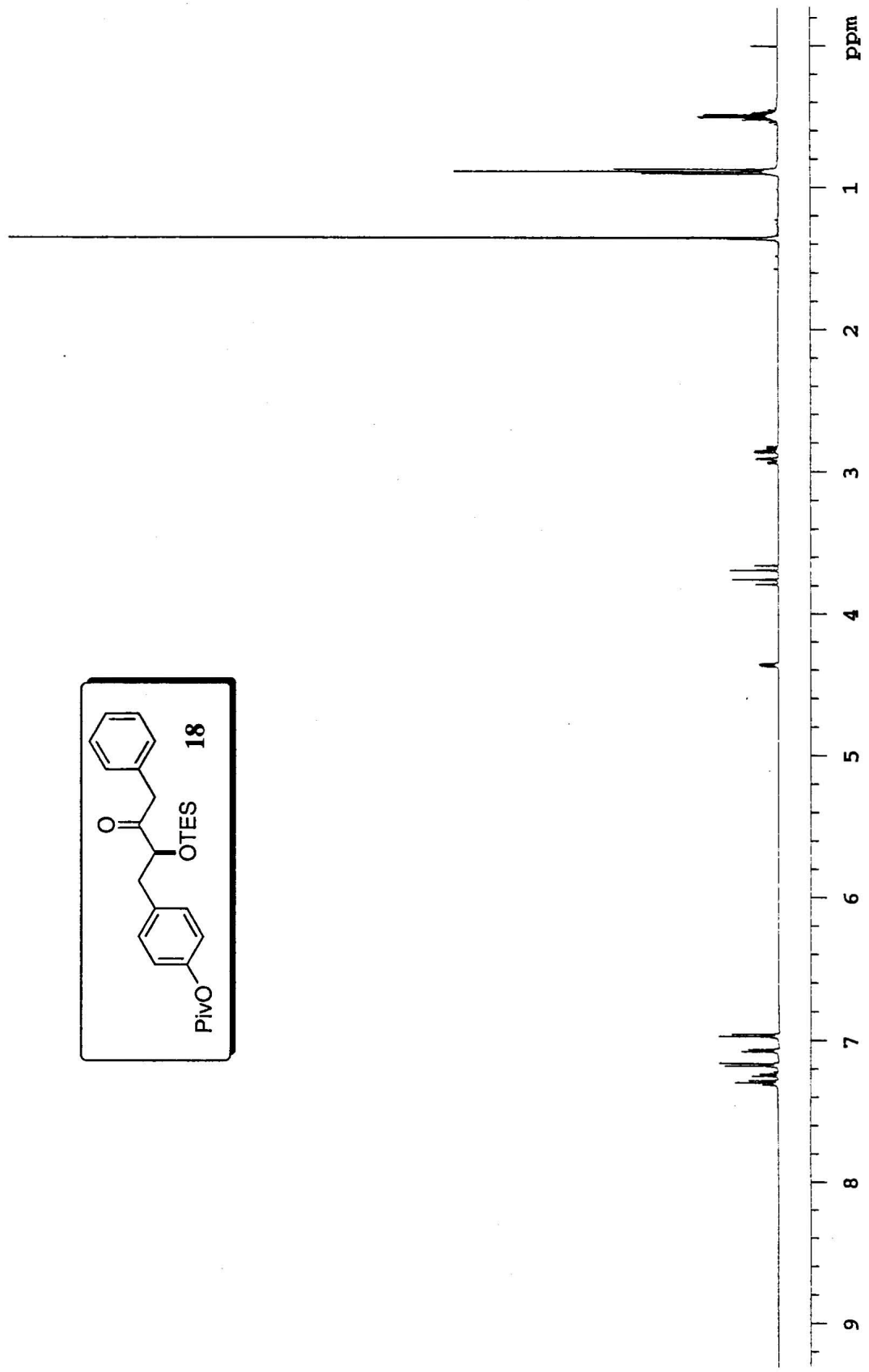
S-17

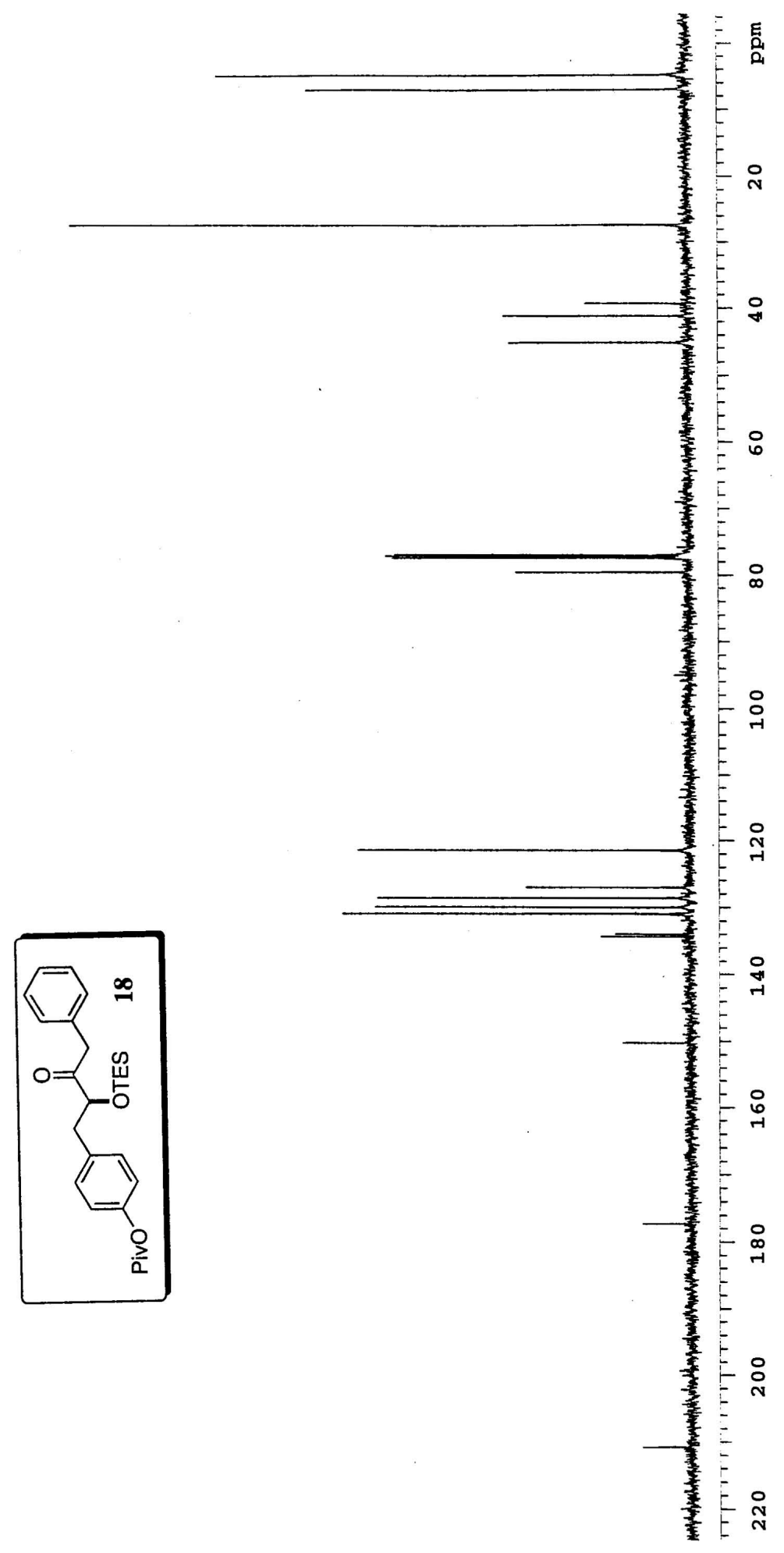


S-18

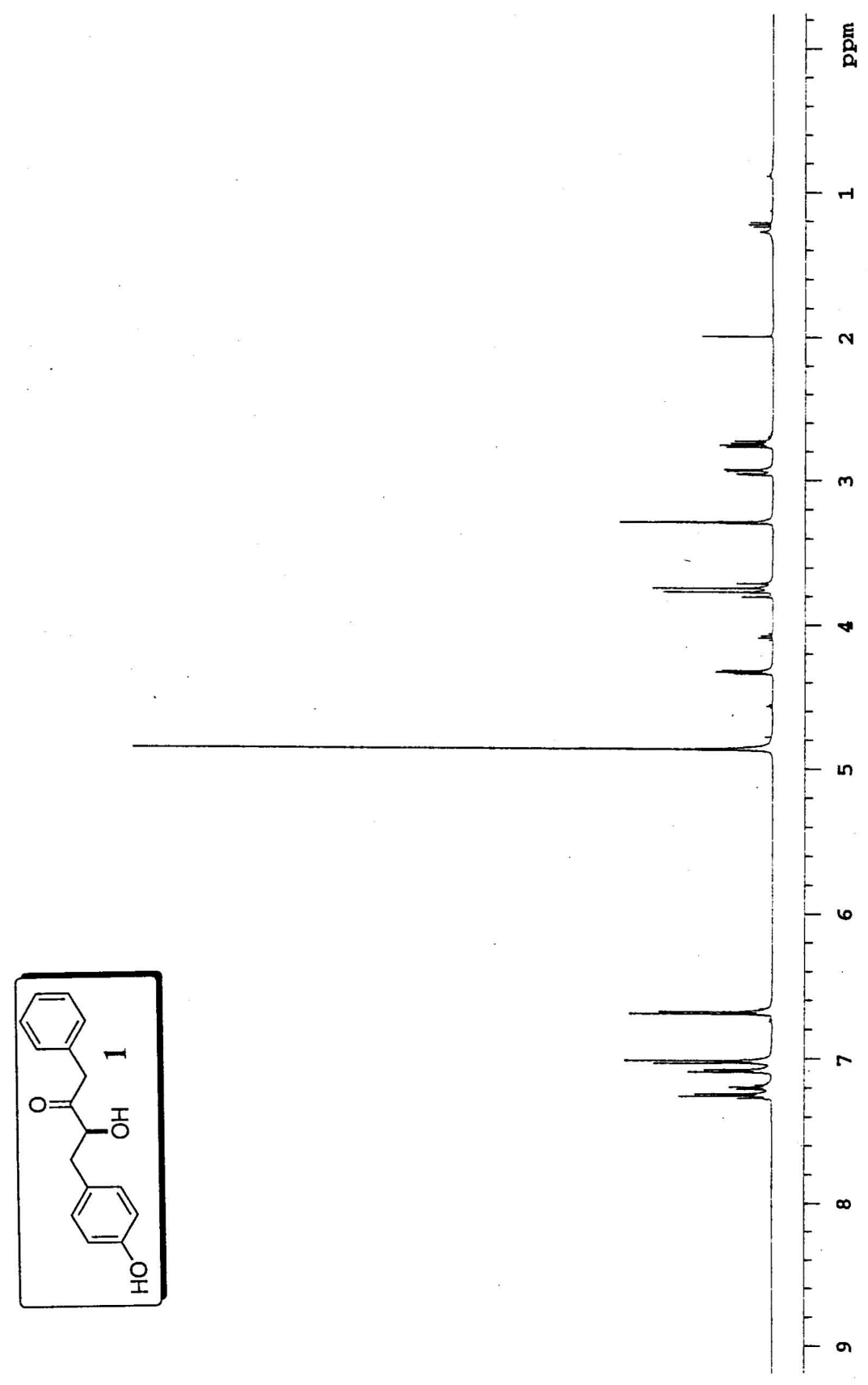

